\title{
Relationship and Mechanism Analysis of Soft-Melt Dropping Properties and Primary-Slag Formation Behaviors of the Mixed Burden in Increasing Lump Ore Ratio
}

\author{
Yun-Fei Li, Zhi-Jun He *, Wen-Long Zhan *D, Wei-Guo Kong, Peng Han, Jun-Hong Zhang \\ and Qing-Hai Pang
}

School of Materials and Metallurgy, University of Science and Technology Liaoning, Anshan 114051, China; lyf101521@163.com (Y.-F.L.); kwg67098@126.com (W.-G.K.); hp978221460@163.com (P.H.); junhongzhang1970@163.com (J.-H.Z.); edikitty@126.com (Q.-H.P.)

* Correspondence: hezhijun@ustl.edu.cn (Z.-J.H.); zhanwenlong288@163.com (W.-L.Z.)

Received: 28 July 2020; Accepted: 14 September 2020; Published: 17 September 2020

\begin{abstract}
At present, cost reduction and environmental protection are the mainstream of blast furnace (BF) development and the high lump ore ratio is an effective means. Therefore, it is significant to explore the relationship and mechanism of burden soft-melt dropping and its primary-slag formation behaviors under increasing lump ore ratio. In this paper, the melt-drop test is carried out on the single ore and mixed burden, and obtained primary-slag properties are subjected to analysis. The experimental results show that the primary-slag of lump ore contains a large amount of $\mathrm{FeO}$ and $\mathrm{SiO}_{2}$, so it simply produces many low melting point compounds, which cause terrible soft-melt dropping properties and primary-slag formation behaviors. Notably, mixing with sinter and pellet can effectively improve both the properties. With the increase in lump ore ratio, the $\mathrm{CaO}$ in the primary-slag decreases, $\mathrm{FeO}$ and $\mathrm{SiO}_{2}$ increase, resulting in the melting temperature of the primary-slag sequentially decreasing and the cohesive zone moves to the low temperature zone. In addition, the maximum pressure difference increases, and the gas permeability deteriorates. Increasing the sinter ratio can overcome the defect of high lump ore ratio that can effectively improve the poor softening performance, melting performance and the position and thickness of the cohesive zone. However, because of the pulverization performance, the maximum pressure difference and gas permeability of the burden become worse.
\end{abstract}

Keywords: lump ore ratio; soft-melt dropping properties; primary-slag formation behaviors; slag phase transformation; formation mechanism

\section{Introduction}

At present, blast furnace $(\mathrm{BF})$ is a high-efficiency mainstream ironmaking process that cannot be replaced and the problems it faces mainly include cost and environmental protection. The reasonable burden structure and BF slag system optimization play significant roles in stabling BF operation, reducing the production cost and improving the level of productivity [1-4]. However, increasing the ratio of lump ore into the $\mathrm{BF}$ can effectively reduce costs and pollution [5-8]. However, during the conversion of ferric oxide to trioxide, the unit cell will expand by $21 \%$, resulting in pulverization, which will affect the permeability by increasing the lump ore ratio. What is more, the reduction in high sinter ore ratio will certainly affect the soft-melt dropping behaviors.

The ratio of lump ore used by companies in Japan and other Asian countries generally exceeds $15 \%$ and some even exceed $20 \%$, which fully demonstrates that the ratio of high-quality lump ore into 
the furnace between $10 \%$ and $20 \%$ will not have a large impact on the operation of the BF. It further proves the feasibility of the high-ratio lump ore into the furnace [5-8]. In Baosteel and Shougang, the ratio of lump ore directly entering the BF can reach $20 \%$. However, some other domestic BFs find it difficult to reach $15 \%$ and some even produce full clinker smelting [9-11]. This is due to the lack of high-grade lump ore in our country. In recent years, the quality and grade of imported ore have also decreased, which leads to the reduction in the smelting economy of lump ore resources.

The ratio of lump ore has an important influence on the metallurgical properties of the burden and $\mathrm{BF}$ operation. In recent years, there are a large number of researchers exploring the function mechanisms of lump ore on softening-melting behaviors of mixed burden. Wu et al. considered that different types of lump ore have different effects on the soft-melt dropping properties and high-quality lump ore has a small impact on the soft-melt dropping properties of the mixed burden. Simultaneously its high temperature metallurgy can meet the requirements of the BF [12,13]. Zhang et al. found that, compared with a single burden, the reduction properties and low-temperature reduction pulverization properties of the mixed burden are superimposed, but the soft-melt dropping properties are not superimposed. In addition, a proper amount of high-quality lump ore ratio will not have a large impact on the ironmaking process [14-16]. Naito et al. revealed that raw materials smelting has a terrible impact on the BF operation, but the metallurgical properties can meet the requirements of BF smelting [17]. Besides, some researchers deem that the temperature range of the single ore primary-slag is wide and the interaction between mixed burden can improve the primary-slag formation behaviors. In addition, others explored the influence of different chemical components on the metallurgical properties of slag [18-25]. However, predecessors have not conducted a comprehensive study on the relationship between softening-melting and primary-slag formation behaviors on the cohesive zone under high lump ratio.

It is of great significance to explore the high-temperature metallurgical properties under high ratio lump ore ratio. This work systematically analyzes the soft-melt dropping properties and primary-slag formation behaviors of the charge under the condition of increasing the lump ore ratio and further analyzes their internal relations and the mechanism. It mainly uses large-scale soft-melt dropping equipment to select lump ore ratios of $15 \%, 20 \%$ and $25 \%$, respectively. Then the obtained primary slags are subjected to chemical composition, slag phase composition and melting properties. Finally, the soft-melt dropping properties and primary-slag formation behaviors are explored, as well as their internal connections. This will provide a theoretical basis for exploring the influence of the ratio of lump ore on the whole BF ironmaking process.

\section{Materials and Methods}

\subsection{Materials}

The iron ores in the experiment are used in actual BF production, including sinter (S-1) with basicity of 1.80, pellet (P-1) and lump ore (O-1). The specific chemical compositions of the samples are shown in Table 1. The $\mathrm{Fe}_{\mathrm{T}}$ mass fraction of $\mathrm{S}-1$ is $58.51 \%$ and $\mathrm{SiO}_{2}$ mass fraction is only $4.84 \%$, which is a typical sinter with high iron, low silicon and high basicity. In addition, for P-1 with the contents of $\mathrm{Fe}_{\mathrm{T}}, \mathrm{SiO}_{2}$ mass fraction sets as $66.54 \%$ and $2.03 \%$, respectively. What is more, the $\mathrm{Fe}_{\mathrm{T}}$ mass fraction of $\mathrm{O}-1$ is $63.38 \%$ and the content of $\mathrm{SiO}_{2}$ is $3.14 \%$, which has high quality and can satisfy the normal smelting requirements.

Table 1. Chemical compositions of iron ore samples (mass fraction, \%).

\begin{tabular}{cccccccccc}
\hline Sample & $\mathrm{Fe}_{\mathbf{T}}$ & $\mathbf{F e O}$ & $\mathrm{SiO}_{\mathbf{2}}$ & $\mathbf{C a O}$ & $\mathrm{Al}_{\mathbf{2}} \mathbf{O}_{3}$ & $\mathbf{M g O}$ & $\mathrm{TiO}_{2}$ & $\mathbf{M n O}$ & $\mathbf{S}$ \\
\hline S-1 & 58.51 & 9.32 & 4.84 & 9.05 & 1.68 & 1.48 & 0.10 & 0.23 & 0.01 \\
P-1 & 66.54 & 0.31 & 2.03 & 1.48 & 0.58 & 0.17 & 0.04 & 0.13 & 0.02 \\
O-1 & 63.38 & 0.48 & 3.14 & 0.04 & 1.25 & 0.06 & 0.14 & 0.18 & 0.02 \\
\hline
\end{tabular}




\subsection{Experimental Procedure}

The test uses a large-capacity iron ore soft-melt dropping detection device with independent intellectual property rights, which is shown in Figure 1. At present, the method for measuring iron ore high temperature load reduction soft-melt dropping properties (GB/T 34211-2017) only regulates the relevant operations and parameters of the experimental process of small drip equipment (500 g); this article, however, refers to large drip equipment (2000 g). The experimental dosage is more, the experimental results are more representative, and the reproducibility is better [26]. The test conditions are determined as follows: The specification of graphite crucible is $\varphi 95 \mathrm{~mm} \times 210 \mathrm{~mm}$ and loads $1 \mathrm{~kg} / \mathrm{cm}^{2}$ of iron-bearing burden. In addition, $80 \mathrm{~g}$ of coke is laid under the burden layer, $60 \mathrm{~g}$ of coke is laid above and the full particle size is $8-12 \mathrm{~mm}$. The heating system and ventilation system of the equipment are shown in Figure 2.

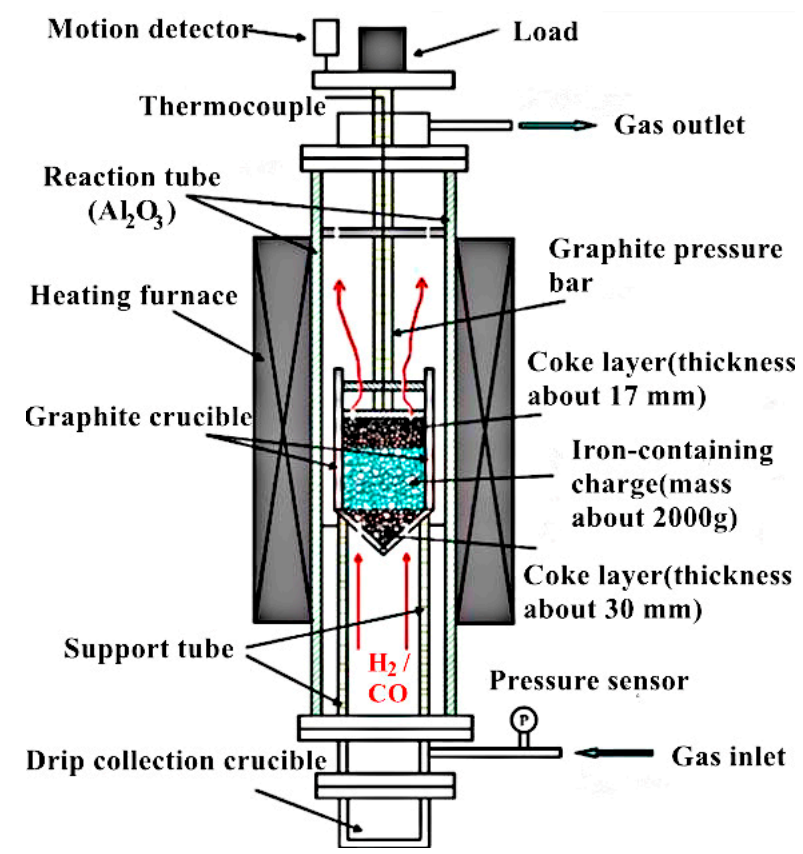

Figure 1. Schematic diagram of iron ores melting and dropping measuring device.

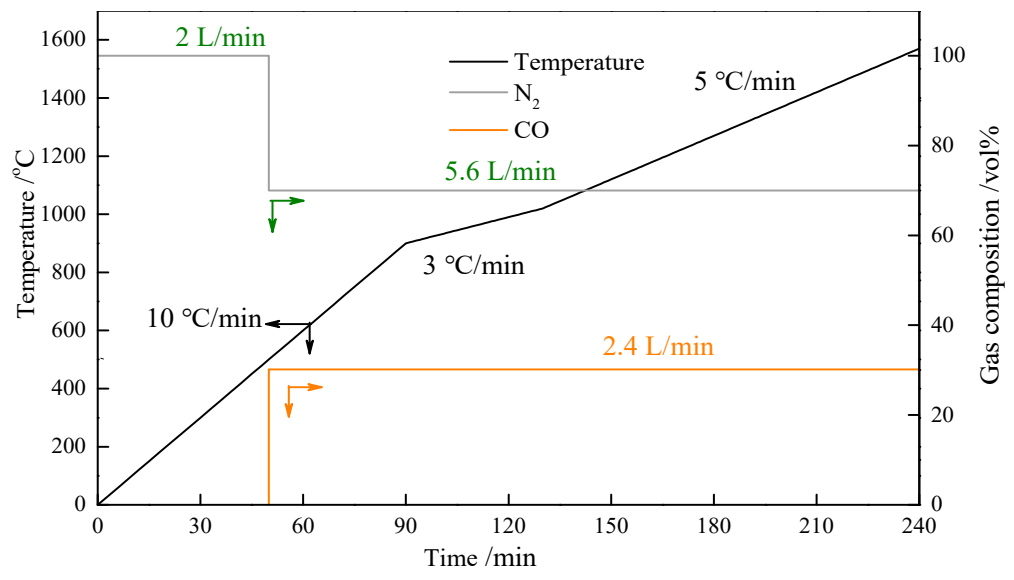

Figure 2. Heating and ventilation program.

\subsection{Melting and Dropping Test Schemes}

According to the actual production of $\mathrm{BF}$ burden alkalinity $\left(\mathrm{w}(\mathrm{CaO}) / \mathrm{w}\left(\mathrm{SiO}_{2}\right)\right.$ is generally $1.3-1.5[27,28]$, the melt-drop experiment scheme selected in this work is shown in Table 2. Schemes 1-3 are three kinds of 
single ore. Schemes 4-6 are the mixed burdens with the sinter ratio unchanged, the pellet ratio decreased, and the lump ore ratio increased. Schemes 7 and 8 keep the lump ore ratio constant at $25 \%$ and change other burdens' ratios.

Table 2. The schemes of melting and dropping experiment.

\begin{tabular}{ccccc}
\hline Scheme & S-1 Ratio & P-1 Ratio & O-1 Ratio & Basicity \\
\hline 1 & 100 & 0 & 0 & 1.87 \\
2 & 0 & 100 & 0 & 0.73 \\
3 & 0 & 0 & 100 & 0.01 \\
4 & 55 & 30 & 15 & 1.44 \\
5 & 55 & 25 & 20 & 1.40 \\
6 & 55 & 20 & 25 & 1.36 \\
7 & 65 & 10 & 25 & 1.45 \\
8 & 75 & 0 & 25 & 1.54 \\
\hline
\end{tabular}

\section{Results and Discussions}

\subsection{Analysis of Softening and Melting Behaviors of Iron-Containing Burden after Increasing Lump Ore Ratio}

\subsubsection{Analysis of the Softening Behaviors}

Shrinkage occurs in the softening process of the burden and the shrinkage rate of the burden can be calculated by Equation (1).

$$
\Delta \mathrm{H}=\frac{\mathrm{H}_{0}-\mathrm{H}_{\mathrm{T}}}{\mathrm{H}_{0}}
$$

where $\Delta \mathrm{H}$ is the shrinkage rate of the burden at a certain temperature, $\% ; \mathrm{H}_{\mathrm{T}}$ is the displacement of the displacement sensor at a certain temperature, $\mathrm{mm} ; \mathrm{H}_{0}$ is the original height of the burden, $\mathrm{mm}$.

The changes in the softening properties of the burden under different burden are shown in Figure 3.

Comparing the shrinkage curves $a, b$ and $c$ in Figure $3 a$, it can be seen that for the single ore, the $\mathrm{T}_{0}$ (temperature at which the burden begins to shrink) and $\mathrm{T}_{10}$ (the temperature at which the burden shrinks $10 \%$ of the lump O-1) and $\mathrm{T}_{40}$ (the temperature at which the burden shrinks by $40 \%$ ) are the smallest, and $\Delta \mathrm{T}$ (the softening temperature range of the burden, $\Delta \mathrm{T}=\mathrm{T}_{40}-\mathrm{T}_{10}$ ) is the widest at $169^{\circ} \mathrm{C}$. In comparison, $\mathrm{T}_{0}$ and $\mathrm{T}_{10}$ of sinter are the largest, $\mathrm{T}_{40}$ is similar to pellet at $1300{ }^{\circ} \mathrm{C}$ and $\Delta \mathrm{T}$ is the narrowest at only $94{ }^{\circ} \mathrm{C}$. Pellet has the highest $\mathrm{T}_{40}$ at $1302{ }^{\circ} \mathrm{C}$ and $\mathrm{T}_{0}, \mathrm{~T}_{10}$ and $\Delta \mathrm{T}$ are between the other two types of single ore. In summary, the softening properties of sinter is the best, pellet is second and lump ore is the worst. This is because lump ore is mainly composed of limonite with loose structure and higher crystal water content. At the same time, it contains higher $\mathrm{Al}_{2} \mathrm{O}_{3}$, which causes it to soften at a lower temperature [24]. High-basicity sinter and self-dissolving pellet have excellent metallurgical properties, strong resistance to deformation and relatively high softening temperature [27].

Comparing the shrinkage curves $\mathrm{d}$, e and $\mathrm{f}$ in Figure $3 \mathrm{~b}$, when the $\mathrm{S}-1$ ratio is constant: the $\mathrm{O}-1$ ratio increases from $15 \%$ to $20 \%$; $\mathrm{T}_{0}$ increases by $9{ }^{\circ} \mathrm{C}$; $\mathrm{T}_{10}$ decreases from $1172{ }^{\circ} \mathrm{C}$ to $1161{ }^{\circ} \mathrm{C}$; $\mathrm{T}_{40}$ increases from $1290{ }^{\circ} \mathrm{C}$ to $1315^{\circ} \mathrm{C} ; \Delta \mathrm{T}$ increases by $36^{\circ} \mathrm{C}$. When the $\mathrm{O}-1$ ratio increases from $20 \%$ to $25 \%$ : $\mathrm{T}_{0}$ rises to $1099{ }^{\circ} \mathrm{C} ; \mathrm{T}_{10}, \mathrm{~T}_{40}, \Delta \mathrm{T}$ all decrease, but the change value is small. In summary, as the ratio of lump ore increases, the $\mathrm{T}_{0}$ increases and $\mathrm{T}_{10}$ decreases in turn. Under the influence of lump ore, the softening properties first deteriorate sharply and as the ratio of lump ore further increases, its influence gradually weakens. The first reason is that as the high softening temperature pellet ratio decreases and the low softening temperature lump ore ratio increases; the second is that the $\mathrm{SiO}_{2}$ content of the lump ore is higher. The increasing ratio makes it easier to react with $\mathrm{FeO}$ at lower temperatures and generate a large amount of low melting point compounds, resulting in a decrease in the $\mathrm{T}_{10}$ of the mixed burden $[22,28]$. 

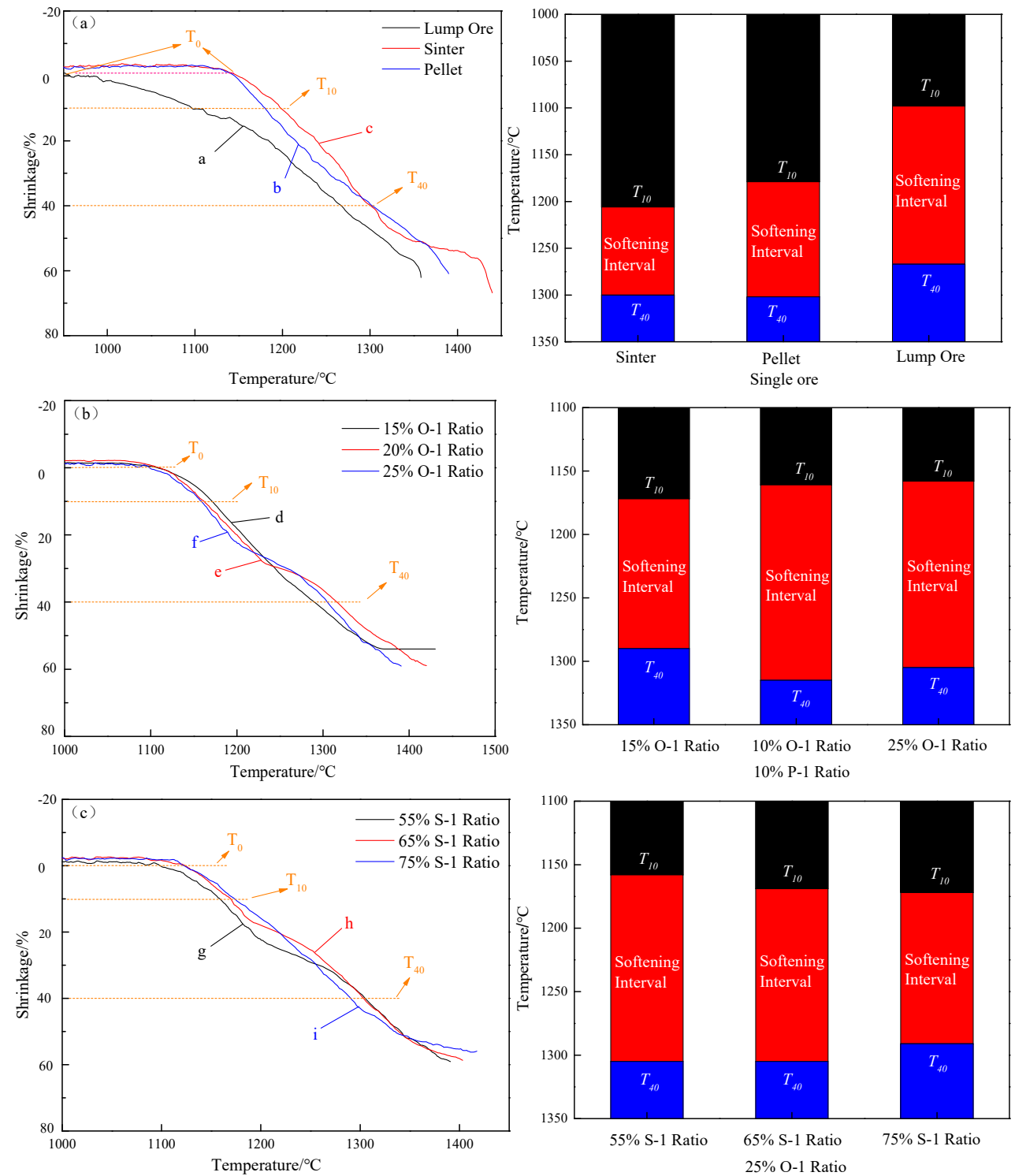

Figure 3. Changes in the softening properties of different burdens. (a) single ores; (b) $55 \%$ sinter ratio; (c) $25 \%$ lump ore ratio.

Comparing the shrinkage curves $\mathrm{g}$, $\mathrm{h}$ and $\mathrm{i}$ in Figure $3 \mathrm{c}$, it can be seen that when the $\mathrm{O}-1$ ratio is $25 \%$ : the $\mathrm{S}-1$ ratio increases from $55 \%$ to $65 \% ; \mathrm{T}_{0}$ changes little; $\mathrm{T}_{10}$ increases by $11^{\circ} \mathrm{C} ; \mathrm{T}_{40}$ of both is $1305{ }^{\circ} \mathrm{C} ; \Delta \mathrm{T}$ is narrowed by $11{ }^{\circ} \mathrm{C}$. When the $\mathrm{S}-1$ ratio increased from $65 \%$ to $75 \%$ : $\mathrm{T}_{0}$ rises to $1099{ }^{\circ} \mathrm{C} ; \mathrm{T}_{0}$ drops $7{ }^{\circ} \mathrm{C} ; \mathrm{T}_{10}$ only increased $3{ }^{\circ} \mathrm{C} ; \mathrm{T}_{40}$ decreases $14{ }^{\circ} \mathrm{C} ; \Delta \mathrm{T}$ reduces from $136{ }^{\circ} \mathrm{C}$ to $119{ }^{\circ} \mathrm{C}$. In summary, as the sinter ratio increases successively, the $\mathrm{T}_{0}$ of the mixed burden decreases, but the amplitude is not large; $\mathrm{T}_{10}$ increases; $\mathrm{T}_{40}, \Delta \mathrm{T}$ decreases. Properly increasing the sintering ratio can effectively improve the softening properties of the high lump ore ratio burden. The reason may be that as the high softening temperature sinter increases, the lower softening temperature pellet ratio decreases. The second is that the sinter phase is mainly calcium ferrite, which has better reduction properties. With the increase in its ratio, the $\mathrm{FeO}$ content is reduced. At the same time, the sinter contains higher $\mathrm{MgO}$ and $\mathrm{CaO}$ that can form a large number of high melting point compounds, which leads to the increase in the $\mathrm{T}_{10}$ of the mixed burden [20-22,28].

In summary, due to its own defects, lump ore has a lower softening temperature, a wide softening range and poor softening performance. However, the performance can be effectively improved by mixing ores, because the interaction between the burden has a positive effect on the softening 
performance $[12,13]$. As the lump ore ratio increases, the $\mathrm{T}_{10}$ gradually decreases due to the increase in low melting point compounds. Under the condition of high lump ore ratio, increasing the high alkalinity sinter ratio can effectively suppress the disadvantages of lump ore.

\subsubsection{Analysis of the Melting Behaviors}

The changes in melting properties of the three single ore are shown in Figure 4a. O-1 has the lowest $\mathrm{T}_{\mathrm{s}}$ (pressure difference steep rise temperature) and $\mathrm{T}_{\mathrm{d}}$ (temperature at which the slag and iron drips), which are $1247^{\circ} \mathrm{C}$ and $1358^{\circ} \mathrm{C}$, respectively. Additionally, $\Delta \mathrm{Tds}$ (burden melting temperature range, $\left.\Delta \mathrm{T}_{\mathrm{ds}}=\mathrm{T}_{\mathrm{d}}-\mathrm{T}_{\mathrm{s}}\right)$ is $111{ }^{\circ} \mathrm{C}$. The maximum $\mathrm{T}_{\mathrm{s}}$ of $\mathrm{P}-1$ is $1321^{\circ} \mathrm{C}, \Delta \mathrm{T}_{\mathrm{ds}}$ is only $69^{\circ} \mathrm{C}$ and $\mathrm{T}_{\mathrm{d}}$ is between the other two. The $\mathrm{T}_{\mathrm{d}}$ of $\mathrm{S}-1$ is as high as $1439^{\circ} \mathrm{C}, \Delta \mathrm{T}_{\mathrm{ds}}$ is the largest and $\mathrm{T}_{\mathrm{s}}$ is second only to pellet. Lump ore containing low melting point compounds has a lower melting temperature $[11,16]$. Thus, the charge melts at a lower temperature and blocks the gap of the material layer, causing the pressure difference to rise sharply at a lower temperature. At the same time, the high melting point compounds contained in it make its dropping temperature higher, so its melting range is wider. However, sinter and pellet containing a large amount of high melting point have a higher melting temperature and narrow melting range.
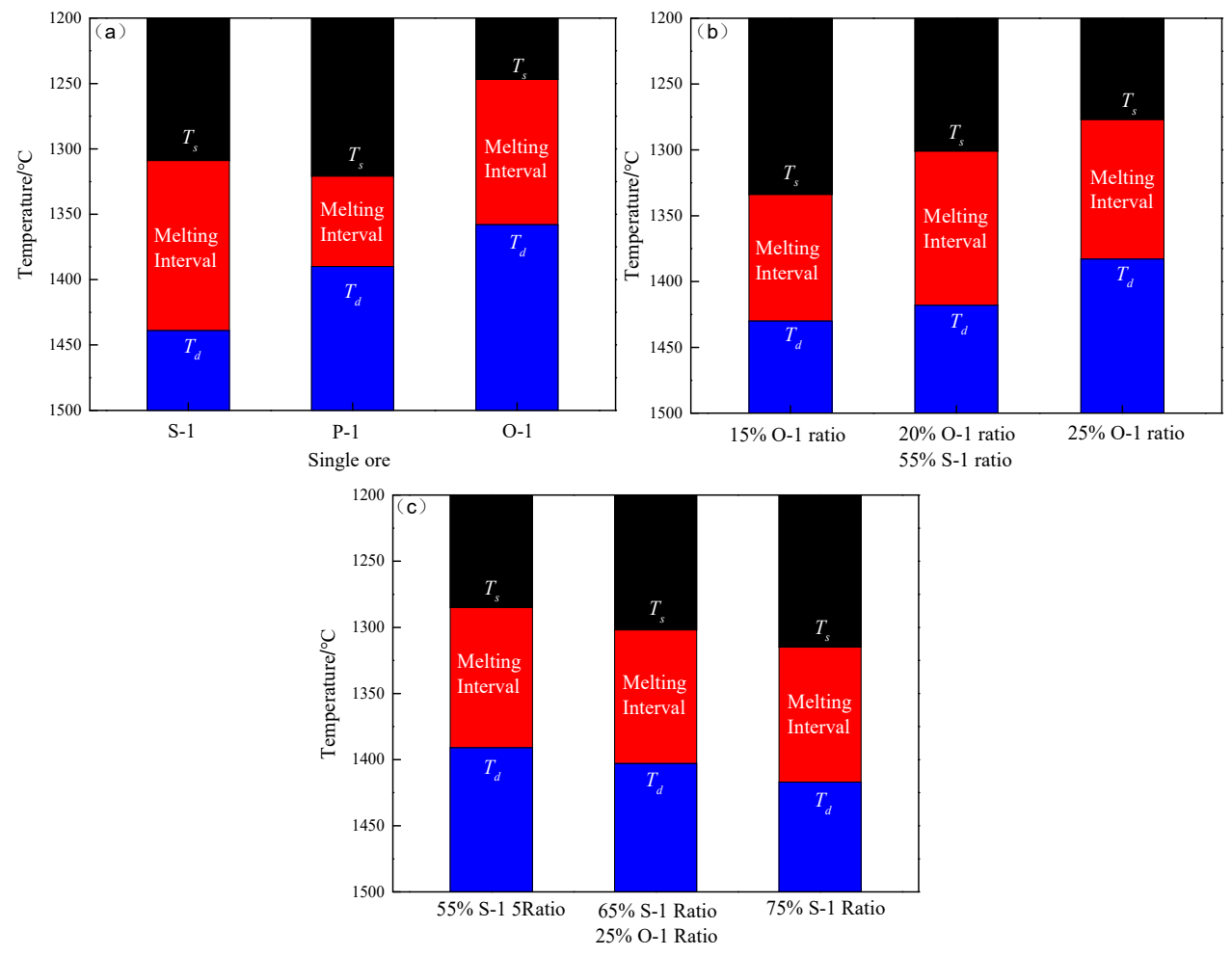

Figure 4. $\Delta \mathrm{T}_{\mathrm{ds}}$ of the different burdens. (a) single ores; (b) $55 \%$ sinter ratio; (c) $25 \%$ lump ore ratio.

The lump ore ratio increases from $15 \%$ to $25 \%$ and the melting characteristics of the mixed burdens are shown in Figure $4 \mathrm{~b}$. When the O-1 ratio increases from $15 \%$ to $20 \%$, the $\mathrm{T}_{\mathrm{s}}$ of the mixed burden decreases by $33^{\circ} \mathrm{C}$, the $\mathrm{T}_{\mathrm{d}}$ decreases from $1430{ }^{\circ} \mathrm{C}$ to $1418{ }^{\circ} \mathrm{C}$, the $\Delta \mathrm{T}_{\mathrm{ds}}$ increases by $21^{\circ} \mathrm{C}$. Meanwhile, the O-1 ratio increased from $20 \%$ to $25 \%$, $\mathrm{T}_{\mathrm{s}}$ dropped to $1285^{\circ} \mathrm{C}, \mathrm{T}_{\mathrm{d}}$ dropped by $16{ }^{\circ} \mathrm{C}, \Delta \mathrm{T}_{\mathrm{ds}}$ dropped from $117^{\circ} \mathrm{C}$ to $106^{\circ} \mathrm{C}$. As the proportion increases, due to the increase in low melting point compounds, the melting start temperature decreases and the temperature at which molten iron appears is lower, which in turn leads to lower dropping temperature.

The sinter ratio increases from $55 \%$ to $75 \%$ and the melting characteristics of the mixed burden are shown in Figure 4c. When the S-1 ratio increases from $55 \%$ to $65 \%$, the $\mathrm{T}_{\mathrm{S}}$ of the mixed burden rises from $1285^{\circ} \mathrm{C}$ to $1302{ }^{\circ} \mathrm{C}, \mathrm{T}_{\mathrm{d}}$ increases by $12{ }^{\circ} \mathrm{C}, \Delta \mathrm{T}_{\mathrm{ds}}$ decreases by $5^{\circ} \mathrm{C}$ and the melting properties 
improve. When the S-1 ratio increased from $65 \%$ to $75 \%, \mathrm{~T}_{\mathrm{s}}$ increased by $13{ }^{\circ} \mathrm{C}, \mathrm{T}_{\mathrm{d}}$ rose to $1417{ }^{\circ} \mathrm{C}$, $\Delta \mathrm{T}_{\mathrm{ds}}$ only increased by $1^{\circ} \mathrm{C}$. With the increase in sinter with greater high melting point compounds, the melting temperature and dropping temperature of the mixed charge likewise increased.

In summary, the lump ore phase is complex, and the melting points of the compounds contained are quite different, so it has a lower $\mathrm{T}_{\mathrm{s}}$ and a wider $\Delta \mathrm{T}_{\mathrm{ds}}$. Further, mixed charge can also effectively improve its performance. When the O-1 ratio increases, the $\Delta \mathrm{T}_{\mathrm{ds}}$ moves to the low temperature area and the melting temperature interval becomes wider. This may be due to the decrease in P-1 with better melting properties and the formation of a large amount of low melting compounds. Under the condition of high lump ore ratio, appropriately increasing the sinter ratio can improve the melting properties of the mixed burden to a certain extent. This may be because the increase in S- 1 has better melting properties. At the same time, the sinter contains higher $\mathrm{MgO}$ and $\mathrm{CaO}$, forming a large amount of high melting point compounds, which leads to the increasing $\mathrm{T}_{\mathrm{d}}$ of the mixed burden [27].

\subsubsection{Analysis of the Maximum Pressure Difference}

The change of $\Delta \mathrm{P}_{\max }$ (maximum pressure difference) of different burdens is shown in Figure 5. As shown in Figure $5 \mathrm{a}$, the $\Delta \mathrm{P}_{\max }$ of lump ore is as high as $12.93 \mathrm{kPa}$, followed by sinter and pellet, which are the smallest at only $3.02 \mathrm{kPa}$. The thermal explosion performance of lump ore and the low-temperature reduction and pulverization performance of sinter are poor, resulting in more powder produced during the high-temperature reduction process, which seriously affects the air permeability of the ore layer. Meanwhile, the self-dissolving pellet has better metallurgical properties and strong toughness.
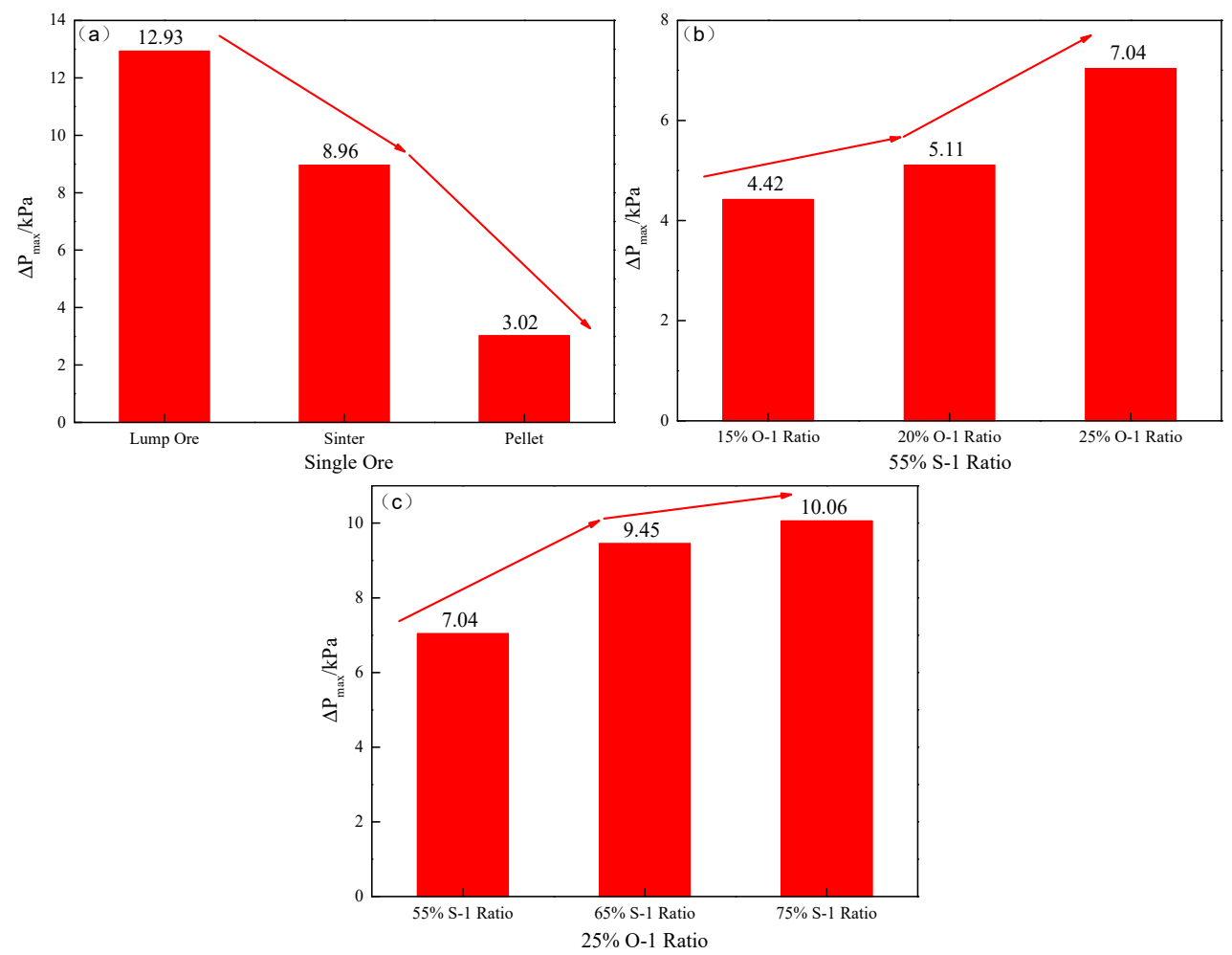

Figure 5. $\Delta \mathrm{P}_{\max }$ of the different burdens. (a) single ores; (b) $55 \%$ sinter ratio; (c) $25 \%$ lump ore ratio.

As shown in Figure $5 b$, when the sinter ratio is constant and the lump ore ratio increases from $15 \%$ to $20 \%$, the $\Delta \mathrm{P}_{\max }$ of the mixed burden only increases by $0.69 \mathrm{kPa}$; while the lump ore ratio rises to $25 \%$, the $\Delta \mathrm{P}_{\max }$ of the mixed burden further increases by $1.93 \mathrm{kPa}$. As the lump ore ratio increases, the powder produced by thermal explosion increases, which blocks the gaps in the material layer and increases the maximum pressure difference. 
The control of the lump ore ratio at $25 \%$, the sinter ratio increasing from $55 \%$ to $75 \%$ and the change of the mixed burden $\Delta \mathrm{P}_{\max }$ is shown in Figure $5 \mathrm{c}$. When the sinter ratio increased from $55 \%$ to $65 \%, \Delta \mathrm{P}_{\max }$ increased from $7.04 \mathrm{kPa}$ to $9.45 \mathrm{kPa}$. However, as the sinter ratio continues to increase to $75 \%$, the change range of $\Delta \mathrm{P}_{\max }$ becomes smaller-only $0.61 \mathrm{kPa}$. As the ratio of sinter increases, the powder produced by low-temperature reduction and pulverization increases, which blocks the gaps in the material layer and increases the maximum pressure difference.

To sum up, due to its poor thermal explosion performance, lump ore produces more powder in the high-temperature reduction, resulting in a larger maximum pressure difference. However, the mixture can effectively reduce the maximum pressure difference. As the lump ore ratio increases, more powder is produced by high-temperature reduction and the maximum pressure difference increases sequentially. As the sinter ratio increases, the powder produced by low-temperature reduction powder further increases and the maximum pressure difference further increases.

\subsubsection{Analysis of the Comprehensive Air Permeability}

The comprehensive air permeability of the cohesive zone can be expressed by its index (S) and its calculation formula is as shown in Equation (2):

$$
\mathrm{S}=\int_{\mathrm{T}_{\mathrm{s}}}^{\mathrm{T}_{\mathrm{d}}}\left(\Delta \mathrm{P}_{\mathrm{T}}-\Delta \mathrm{P}_{\mathrm{s}}\right) \mathrm{dT}
$$

where $\Delta \mathrm{P}_{\mathrm{T}}$ is the pressure difference at temperature $\mathrm{T}$ and $\Delta \mathrm{P}_{\mathrm{S}}$ is the pressure difference at temperature $\mathrm{T}_{\mathrm{S}}$.

The change of the comprehensive air permeability index of different burdens is shown in Figure 6. The $S$ value of the three kinds of single ore is shown in Figure 6a. The maximum $S$ value of lump ore is $680 \mathrm{kPa} \cdot{ }^{\circ} \mathrm{C}$; the air permeability is the worst. The $\mathrm{S}$ value of pellet is only $221 \mathrm{kPa} \cdot{ }^{\circ} \mathrm{C}$; the air permeability is the best, and sinter is located between pellet and lump ore. Lump ore has a large $\Delta \mathrm{P}_{\max }$, while its melting temperature is low and the interval is wide, so its $S$ value is large. Although the $\Delta \mathrm{P}_{\max }$ of sinter is second only to lump ore, it has a higher $\mathrm{T}_{\mathrm{s}}, \mathrm{T}_{\mathrm{d}}$ and a narrow $\Delta \mathrm{T}_{\mathrm{ds}}$, so its $\mathrm{S}$ value is smaller than that of lump ore. However, the $\Delta \mathrm{P}_{\max }$ of pellet is smaller, the melting performance is higher, and the gas permeability is the best.

As shown in Figure 6b, when the sinter ratio is constant and the lump ore ratio increases from $15 \%$ to $20 \%$, the $S$ value changes little, which has little effect on its air permeability. When the lump ore ratio increases from $20 \%$ to $25 \%$, the $S$ value increases from $273 \mathrm{kPa} \cdot{ }^{\circ} \mathrm{C}$ to $434 \mathrm{kPa} \cdot{ }^{\circ} \mathrm{C}$ and the air permeability becomes worse. According to the above, as the lump ore ratio increases, the maximum pressure difference increases successively, the melting performance successively deteriorates, and the $S$ value successively increases.

The lump ore ratio is controlled to be $25 \%$, the sinter ratio increases from $55 \%$ to $75 \%$ and the change of the $S$ value of the mixed burden is shown in Figure $6 \mathrm{c}$. When the sinter ratio increased from $55 \%$ to $65 \%$, the $\mathrm{S}$ value increased by $93 \mathrm{kPa} \cdot{ }^{\circ} \mathrm{C}$. As the ratio increases to $75 \%$, the $\mathrm{S}$ value continues to increase to $613 \mathrm{kPa} \cdot{ }^{\circ} \mathrm{C}$. According to the above, as the sinter ratio increases, although the melting performance becomes better, the change range is smaller than the pressure difference and the air permeability worsens.

In summary, because lump ore has a larger pressure difference, a lower melting temperature and a wider melting range, its air permeability is poor. Being mixed with sinter and pellet can effectively improve its air permeability. With the increase in lump ore ratio, the pressure difference gradually increases, the melting temperature decreases, the interval becomes wider and the air permeability becomes worse. When the sinter ratio increases, its influence on the maximum pressure difference is greater than that on the melting performance, so the gas permeability worsens. 

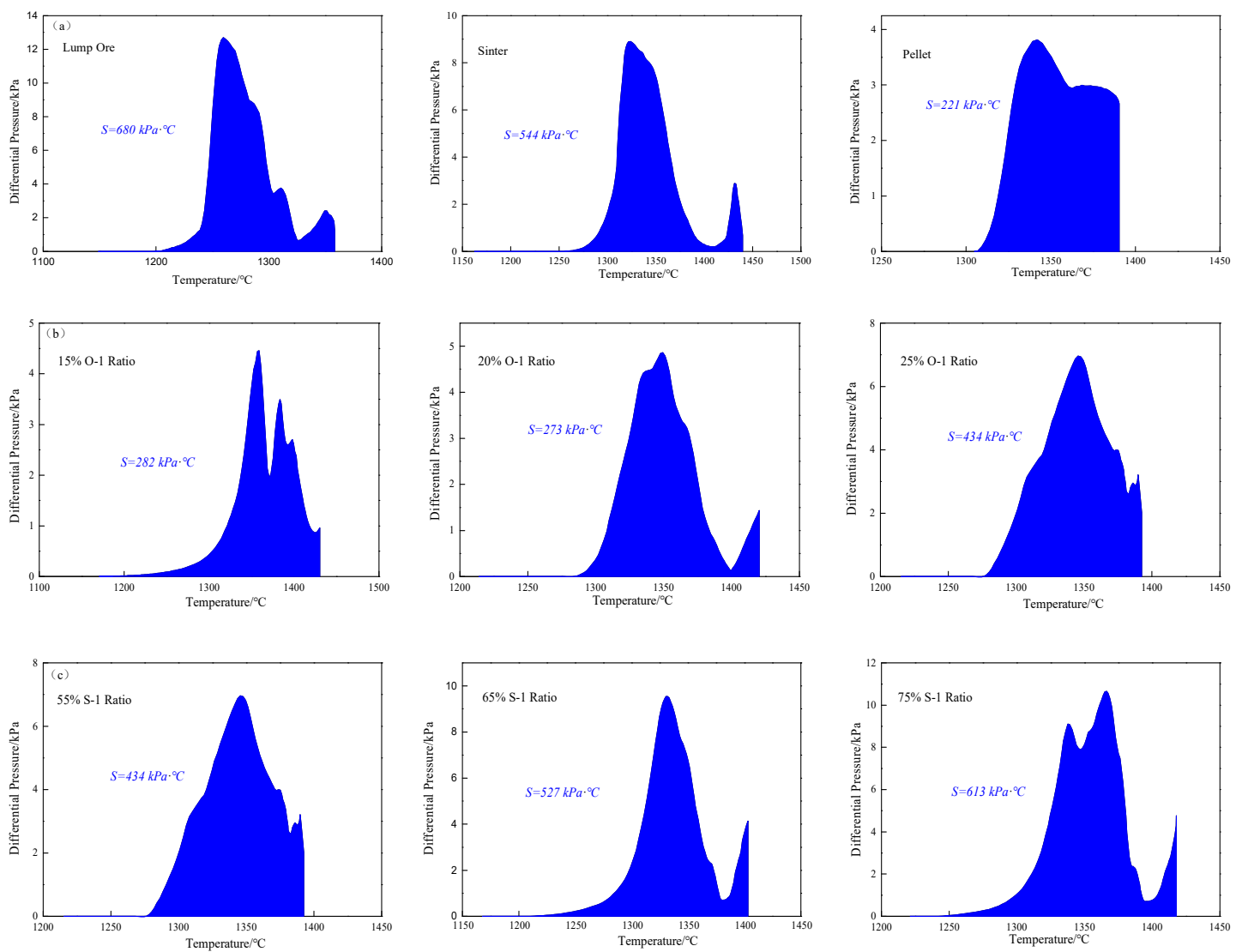

Figure 6. S value of the different burdens. (a) single ores; (b) 55\% sinter ratio; (c) $25 \%$ lump ore ratio.

\subsubsection{Analysis of the Cohesive Zone Position}

The position change of the cohesive zone in different burdens is shown in Figure 7. The position of the cohesive zone of the three single ore is shown in Figure 7a. The cohesive zone of the lump ore is the thickest, up to $260^{\circ} \mathrm{C}$. Further, it is in a very low temperature zone, so its air permeability of the burden is very poor. In comparison, the cohesive zone of sinter ranges from $1206^{\circ} \mathrm{C}$ to $1439^{\circ} \mathrm{C}$ and the temperature zone of the cohesive zone is the highest with a thickness of $233^{\circ} \mathrm{C}$. The cohesive zone of pellet is the thinnest, with a temperature range of $1179{ }^{\circ} \mathrm{C}-1390{ }^{\circ} \mathrm{C}$ and the melting temperature range that has the greatest influence on gas permeability is the smallest and has the best gas permeability. Based on the above, it can be seen that the lump ore contains more complex compounds, has a lower $\mathrm{T}_{10}$ and a higher $\mathrm{T}_{\mathrm{d}}$, so the thickness of the cohesive zone is wider.

As shown in Figure $7 \mathrm{~b}$, when the sinter ratio is constant and the lump ore ratio increases from $15 \%$ to $20 \%$, the thickness of the cohesive zone changes very little. However, the range of melting temperature increases, the air permeability worsens and the cohesive zone moves to the low temperature area. When the lump ore ratio increased from $20 \%$ to $25 \%$, although the thickness of the cohesive zone decreased by $24^{\circ} \mathrm{C}$, it moved further to the low temperature zone. As the lump ore ratio increases, due to the increase in low melting point compounds, the $\mathrm{T}_{10}$ is lower. Additionally, the sinter and pellet play leading roles in the $T_{d}$, so the variation range of $T_{d}$ is less than the $T_{10}$ and the cohesive zone becomes thicker. 

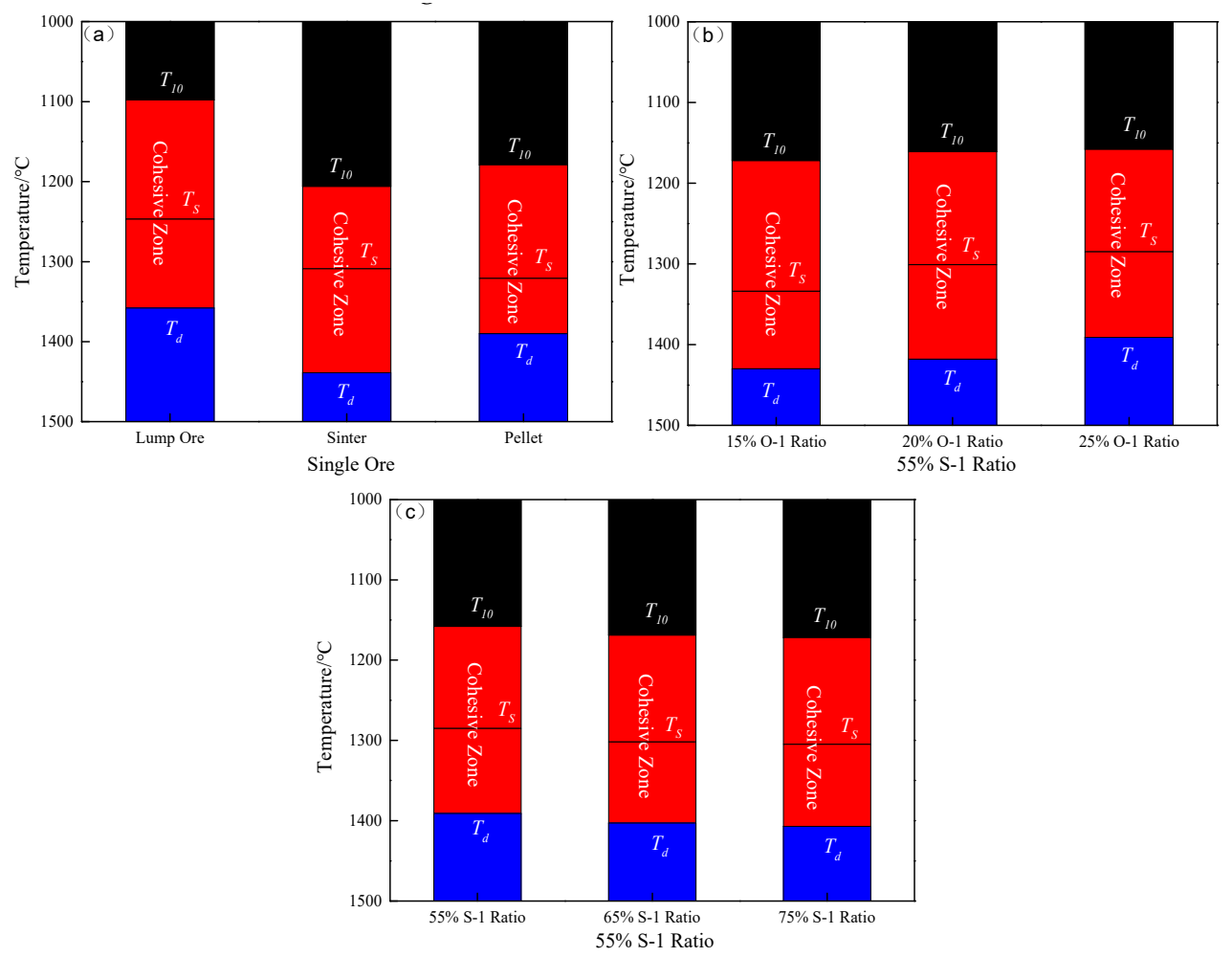

Figure 7. Temperature range of the cohesive zone in different burdens. (a) single ores; (b) 55\% sinter ratio; (c) $25 \%$ lump ore ratio.

The control of the lump ore ratio is $25 \%$, the sinter ratio increases from $55 \%$ to $75 \%$ and the change in the mixed burden cohesive zone temperature range is shown in Figure $7 \mathrm{c}$. When the sinter ratio increases from $55 \%$ to $65 \%$, the thickness of the cohesive zone changes very little and the melting temperature range only narrows by $5{ }^{\circ} \mathrm{C}$, and the whole cohesive zone moves to the high temperature zone by $8{ }^{\circ} \mathrm{C}$. While the sinter ratio increases to $75 \%$, although the cohesive zone thickens by $11^{\circ} \mathrm{C}$, its melting temperature range only increases by $1{ }^{\circ} \mathrm{C}, \mathrm{T}_{\mathrm{d}}$ increases by $14^{\circ} \mathrm{C}$ and the cohesive zone moves to the high temperature zone. Increasing the sinter ratio, the softening performance and melting performance improve, so the performance of the cohesive zone likewise improves.

In summary, the lump ore has a lower soft-melt temperature and a thicker cohesive zone. Mixed charge can effectively improve the performance of lump ore cohesive zone. As the lump ore ratio increases, the performance of the cohesive zone worsens, and increasing the sinter ratio has a certain positive effect on the formation of the cohesive zone.

\subsection{Analysis of Primary-Slag Formation Behavior of Iron-Bearing Burden after Increasing Lump Ore Ratio}

In order to further explore the change and mechanism of the soft-melt dropping properties of the mixed burden with increasing lump ore ratio, the maximum pressure difference and the temperature at the maximum pressure difference are determined according to the above-mentioned test. Then the test is stopped at this temperature and the graphite crucible is dissected to extract the primary slag. The dissecting result is shown in Figure 8. We used Rigaku D/MAX-2500 X-ray diffractometer (Tokyo, Japan) to analyze its mineral composition; the results are shown in Figure 9. The XRF-1800 $X$-ray fluorescence analysis equipment is used for chemical composition analysis. The results of the chemical composition of the primary slag formed by six groups of burden are shown in Table 3. At the same time, the melting point was detected by the HRHN-5F melting point equipment. The melting process is shown in Figure 10. Among them, deformation temperature is the temperature at which the tip end of the cone is rounded or the cone begins to tilt; the softening start temperature is when the tip of the cone becomes curved; hemispherical temperature is the time when the cone turns into a 
hemisphere; when the cone reaches the flow temperature, it is completely flat on the cone holder with no obvious shape. The results of the melting properties are shown in Table 4.

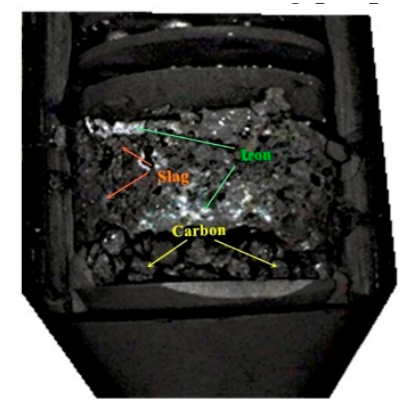

Figure 8. Morphology of the dissecting crucibles.
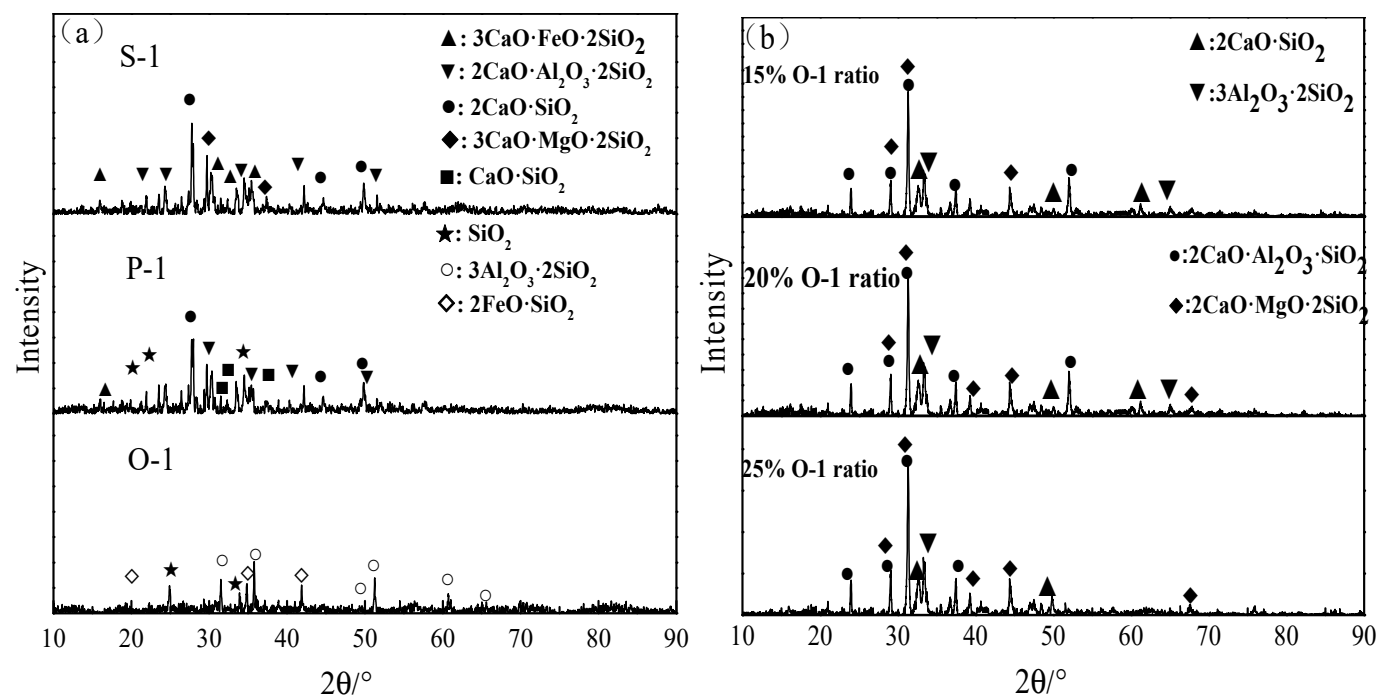

Figure 9. The XRD diffraction pattern of the primary slag. (a) single ores; (b) 55\% sinter ratio

Table 3. Chemical composition of no dropping slag samples, $\%$.

\begin{tabular}{cccccc}
\hline Sample & $\mathbf{F e O}$ & $\mathrm{CaO}$ & $\mathrm{SiO}_{\mathbf{2}}$ & $\mathrm{Al}_{\mathbf{2}} \mathbf{O}_{\mathbf{3}}$ & $\mathrm{MgO}$ \\
\hline $\mathbf{1}$ & 8.61 & 46.17 & 27.92 & 12.20 & 5.10 \\
$\mathbf{2}$ & 8.52 & 45.87 & 27.75 & 11.69 & 6.17 \\
$\mathbf{3}$ & 48.49 & 2.06 & 37.24 & 10.76 & 1.45 \\
$\mathbf{4}$ & 5.56 & 47.06 & 32.15 & 8.58 & 6.27 \\
$\mathbf{5}$ & 6.66 & 43.06 & 35.08 & 8.71 & 6.50 \\
$\mathbf{6}$ & 8.78 & 39.74 & 36.66 & 8.34 & 6.48 \\
\hline
\end{tabular}

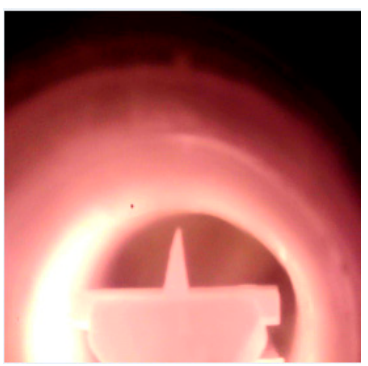

Deformation temperature

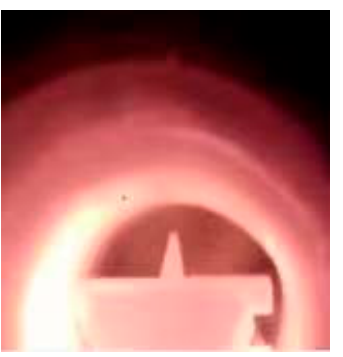

Softening temperature

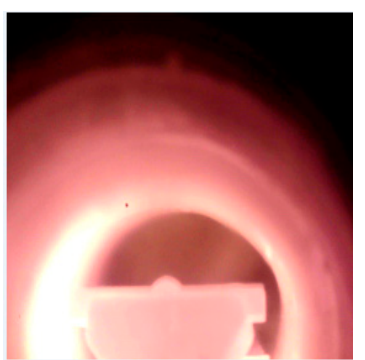

Hemispherical temperature

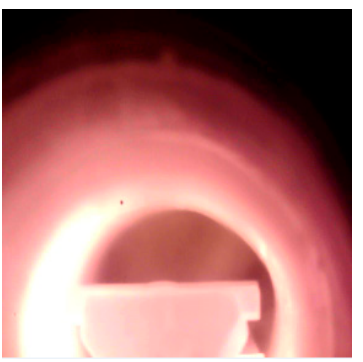

Flow temperature

Figure 10. The change behaviors of sample in the heating process. 
Table 4. The melting temperature of the slags with different furnace burden.

\begin{tabular}{ccccc}
\hline Scheme & $\begin{array}{c}\text { Deformation } \\
\text { Temperature } /{ }^{\circ} \mathbf{C}\end{array}$ & $\begin{array}{c}\text { Softening } \\
\text { Temperature } /{ }^{\circ} \mathbf{C}\end{array}$ & $\begin{array}{c}\text { Hemispheric } \\
\text { Temperature } /{ }^{\circ} \mathbf{C}\end{array}$ & $\begin{array}{c}\text { Flow } \\
\text { Temperature } /{ }^{\circ} \mathbf{C}\end{array}$ \\
\hline 1 & 1310 & 1367 & 1386 & 1423 \\
2 & 1185 & 1203 & 1220 & 1235 \\
3 & 1089 & 1098 & 1107 & 1125 \\
4 & 1219 & 1313 & 1315 & 1326 \\
5 & 1205 & 1305 & 1310 & 1328 \\
6 & 1185 & 1280 & 1286 & 1310 \\
\hline
\end{tabular}

According to the detection results of the primary slag of the single ore, it can be seen that both sinter and pellet are alkaline iron-containing burden; therefore, the formed primary slag has a higher $\mathrm{CaO}$ content. At the same time, due to their better reducibility, the formation of primary-slag $\mathrm{FeO}$ content is lower than other acid burden [27]. For sinter, the FeO content of the primary slag is relatively low. This is because the sinter is loose and porous and the iron-containing mineral composition is mainly calcium ferrite, which has high reducibility and reduces the $\mathrm{FeO}$ content of the primary slag. In addition, due to the addition of more $\mathrm{CaO}$ and $\mathrm{MgO}$ in the production process of sinter, the content of $\mathrm{CaO}$ and $\mathrm{MgO}$ in the primary slag is relatively the highest, forming high melting point minerals, such as $2 \mathrm{CaO} \cdot \mathrm{SiO}_{2}$, etc., which makes the melting temperature and $\mathrm{T}_{\mathrm{d}}$ of sinter increase, as well as the melting zone to move to the high temperature zone and the thickness of the cohesive zone to increase. The pellet has a high content of $\mathrm{Al}_{2} \mathrm{O}_{3}$, but because it is a self-fluxing pellet, it has better reduction properties and low $\mathrm{FeO}$ content in the primary slag, which makes its cohesive zone properties better than the other two.

On the other hand, the content of $\mathrm{CaO}$ in lump ore is extremely low and the oxides that begin to form slag are mainly $\mathrm{FeO}, \mathrm{SiO}_{2}, \mathrm{Al}_{2} \mathrm{O}_{3}$. Although the slag phase contains high melting point compounds such as mullite $\left(3 \mathrm{Al}_{2} \mathrm{O}_{3} \cdot 2 \mathrm{SiO}_{2}, 1940^{\circ} \mathrm{C}\right)$ and silicon dioxide $\left(\mathrm{SiO}_{2}, 1723^{\circ} \mathrm{C}\right)$. However, the melting point of iron olivine $\left(2 \mathrm{FeO} \cdot \mathrm{SiO}_{2}, 1205^{\circ} \mathrm{C}\right)$ is very low, resulting in lump ore drips having a lower temperature. The sinter and self-fluxing pellet primary-slag phase contain a large amount of $\mathrm{CaO}$ and the melting point of the compounds is higher, which makes the upper edge temperature of the cohesive zone of the basic iron-containing burden higher than the lump ore. As the reduction progresses, the FeO content in the slag phase decreases and the mineral composition of the slag phase also changes. The newly produced slag phase is magnesia feldspar $\left(2 \mathrm{CaO} \cdot \mathrm{MgO} \cdot 2 \mathrm{SiO}_{2}, 1454^{\circ} \mathrm{C}\right)$, chrysotile $\left(2 \mathrm{CaO} \cdot \mathrm{Al}_{2} \mathrm{O}_{3} \cdot \mathrm{SiO}_{2}\right.$, $\left.1593{ }^{\circ} \mathrm{C}\right)$, calcium olivine $\left(2 \mathrm{CaO} \cdot \mathrm{SiO}_{2}, 2153{ }^{\circ} \mathrm{C}\right)$, monocalcium silicate $\left(\mathrm{CaO} \cdot \mathrm{SiO}_{2}, 1550{ }^{\circ} \mathrm{C}\right)$. Therefore, the primary slag of sinter and pellet has a high melting temperature and high viscosity and needs to be able to flow freely and separate from the molten iron at a higher temperature, thus exhibiting a higher lower edge temperature of the cohesive zone.

According to the detection results of the primary slag of the mixed burden, when the sinter is matched with different ratios of pellet and lump ore to form a mixed burden, the main mineral compositions of the primary slag, such as feldspar $\left(2 \mathrm{CaO} \cdot \mathrm{MgO} \cdot 2 \mathrm{SiO}_{2}\right)$, calcite $\left(2 \mathrm{CaO} \cdot \mathrm{Al}_{2} \mathrm{O}_{3} \cdot \mathrm{SiO}_{2}\right)$, dicalcium silicate $\left(2 \mathrm{CaO} \cdot \mathrm{SiO}_{2}\right)$ and mullite $\left(3 \mathrm{Al}_{2} \mathrm{O}_{3} \cdot 2 \mathrm{SiO}_{2}\right)$ change little. However, as the lump ore ratio increases successively, the content of $\mathrm{CaO}$ in the primary slag decreases, the contents of $\mathrm{FeO}$ and $\mathrm{SiO}_{2}$ increase and the contents of $\mathrm{Al}_{2} \mathrm{O}_{3}$ and $\mathrm{MgO}$ are similar. Therefore, the high melting point slag phase decreases and the primary-slag melting temperature decreases, resulting in reductions in the softening start temperature, melting temperature and dropping temperature. The cohesive zone moves to the low temperature zone and the properties deteriorates successively.

\section{Conclusions}

1. The ore phase of lump ore is more complicated and the primary slag contains a large amount of $\mathrm{FeO}$ and $\mathrm{SiO}_{2}$. During the high temperature reduction process, it is easy to produce a large amount of low melting point compounds, resulting in lower softening temperature and melting 
temperature, thicker cohesive zone, larger maximum pressure difference, poor air permeability and poor melting performance of the primary slag. On the other hand, by being mixed with sinter and pellet, all the properties can be effectively improved.

2. With the increase in lump ore ratio, the $\mathrm{CaO}$ in the primary slag decreases, and $\mathrm{FeO}$ and $\mathrm{SiO}_{2}$ increase, resulting in the decrease in high melting point compounds in the primary slag. The melting temperature of the primary slag sequentially decreases, resulting in the softening temperature and melting temperature being reduced. The cohesive zone moves to the low temperature zone. Meanwhile, the maximum pressure difference increases, and the gas permeability deteriorates.

3. Under the condition of high lump ore ratio, increasing the sinter ratio can raise the high melting point compounds produced during the high temperature reduction process, so it can effectively improve the poor softening performance, melting performance and the position and thickness of the cohesive zone. However, due to its own metallurgical properties that easily produce a large amount of powder, which leads to the deterioration of the maximum pressure difference and gas permeability of the burden.

Author Contributions: Conceptualization, funding acquisition, methodology, Z.-J.H.; Formal analysis, supervision, writing-review \& editing, W.-L.Z.; data curation, methodology, writing-original draft, Y.-F.L.; Validation, W.-G.K.; Validation, P.H.; Supervision, J.-H.Z.; Validation, Q.-H.P. All authors have read and agreed to the published version of the manuscript.

Funding: The National Natural Science Foundation of China (No. 51874171, 51974154), University of Science and Technology Liaoning Talent Project Grants (No. 601011507-05).

Conflicts of Interest: The authors declare no conflict of interest.

\section{References}

1. Chakravarty, S.; Bhattacharyya, P.; Chatterjee, S.S.; Singh, B.N. Utilisation of Iron ore Fines in Alternative Iron making processes-An Indian perspective. Nature 2000, 334, 338-340.

2. Yu, Y.H.; Feng, G.S.; Su, D.X. Measures of decreasing BF fuel consumption and improving sinter performance in guofeng. J. Iron Steel Res. Int. 2008, 15, 9-28. [CrossRef]

3. An, X.W.; Wang, J.S.; Lan, R.Z.; Han, Y.H.; Xue, Q.G. Softening and Melting Behavior of Mixed Burden for Oxygen BF. J. Iron Steel Res. Int. 2013, 20,11-16. [CrossRef]

4. Kawamura, K.; Shui, V.H. Pilot plant experience in electron-beam treatment of iron-ore sintering flue gas and its application to coal boiler flue gas cleanup. Radiat. Physics Chem. 1984, 24, 117-127. [CrossRef]

5. Lu, W.K. The Search for an Economical and Environmentally Friendly Ironmaking Process. Metall. Mater. Trans. B 2001, 32B, 757-762. [CrossRef]

6. Prakash, S. Non-isothermal kinetics of iron-ore reduction. Ironmak. Steelmak. 1994, 21, 237-243.

7. Ellis, B.G.; Loo, C.E.; Witchard, D. Effect of ore properties on sinter bed permeability and strength. Ironmak. Steelmak. 2007, 34, 99-108. [CrossRef]

8. Nagahiro, K.; Okazaki, T.; Nishino, M. Activities and technologies for environmental protection at Nippon Steel: A perspective. Ironmak. Steelmak. 2005, 32, 227-234. [CrossRef]

9. Zhang, S.; Xue, X.; Liu, X.; Duan, P.; Yang, H.; Jiang, T.; Wang, D.; Liu, R. Current situation and comprehensive utilization of iron ore tailing resources. J. Min. Sci. 2006, 42, 403-408. [CrossRef]

10. Liu, J.; Zhang, H.; Zhou, M.; Zhai, L.W.; Zhang, H.; Xu, L.B. Rational burden structure of BF based on softening and melting property. Iron Steel 2016, 51, 11-15.

11. Wu, S.; Han, H.; Liu, X.; Wang, H.; Xue, F. Erratum to: Highly effective use of Australian Pilbara blend lump ore in a BF. Revue Métallurgie 2010, 107, 187-193. [CrossRef]

12. Wu, S.; Han, H.; Xu, H.; Wang, H.; Liu, X. Increasing lump ores ratio in BF based on the high-temperature interactivity of iron bearing materials. ISIJ Int. 2010, 50, 686. [CrossRef]

13. Wu, S.L.; Xu, H.F.; Tian, Y.Q. Evaluation of lump ores for use in modern BFs as part of mixed burden practice. Ironmak. Steelmak. 2009, 36, 19-23. [CrossRef] 
14. Tao, J.; Yang, G.Q.; Zhang, J.L.; Shao, J.G.; Fu, Y.D.; Wan, D. Effect of Mixed Charge of Ore and Lump Coal on the Softening-Melting Property of the Burden; John Wiley \& Sons: Hoboken, NJ, USA, 2013.

15. Li, X.; Zhang, J.; Su, B.; Yao, C.; Liu, X.; Zhang, C. Performance evaluation of lump ores for BF based on principal component analysis. J. Cent. South Univ. Sci. Technol. 2016, 47, 2943-2950.

16. Wang, X.Z.; Zhang, J.L.; Liu, Z.J.; Liu, X.L.; Wang, R.R.; Xu, Z.T. Influence of lump ore on metallurgical properties of BF burden. Research Iron Steel 2017, 5, 4-8.

17. Nishimura, T.; Higuchi, K.; Naito, M.; Kunitomo, K. Evaluation of Softening, Shrinking and Melting Reduction Behavior of Raw Materials for BF. ISIJ Int. 2011, 51, 1316. [CrossRef]

18. Stefania, G.; Elżbieta, J.R. The influence of small particle on the fluidity of BF slag cement paste containing superplasticizers. Constr. Build. Mater. 2011, 26, 411-415.

19. Gan, L.; Zhang, C.; Zhou, J.; Shangguan, F. Continuous cooling crystallization kinetics of a molten BF slag. J. Non Cryst. Solids 2012, 358, 20-24. [CrossRef]

20. Kim, J.R.; Lee, Y.S.; Min, D.J.; Jung, S.M.; Yi, S.H. Influence of $\mathrm{MgO}$ and $\mathrm{Al}_{2} \mathrm{O}_{3}$ contents on viscosity of $\mathrm{BF}$ type slags containing FeO. ISIJ Int. 2004, 44, 1291-1297. [CrossRef]

21. Tang, X.L.; Zhang, Z.T.; Guo, M.; Zhang, M.; Wang, X.D. Viscosities Behavior of CaO-SiO $2-\mathrm{MgO}_{2} \mathrm{Al}_{2} \mathrm{O}_{3} \mathrm{Slag}$ with Low Mass Ratio of $\mathrm{CaO}$ to $\mathrm{SiO}_{2}$ and Wide Range of $\mathrm{Al}_{2} \mathrm{O}_{3}$ Content. J. Iron Steel Res. Int. 2011, 18, 1-17. [CrossRef]

22. Lee, Y.S.; Min, D.J.; Jung, S.M.; Yi, S.H. Influence of Basicity and FeO Content on Viscosity of BF Type Slags Containing FeO. ISIJ Int. 2004, 44, 1283. [CrossRef]

23. Kumar, S.; Kumar, R.; Mehrotra, S.P. Influence of granulated BF slag on the reaction, structure and properties of fly ash based geopolymer. J. Mater. Sci. 2010, 45, 607-615. [CrossRef]

24. Wu, S.L.; Huang, W.; Kou, M.Y.; Liu, X.L.; Du, K.P.; Zhang, K.F. Influence of $\mathrm{Al}_{2} \mathrm{O}_{3}$ Content on Liquid Phase Ratio and Fluidity of Primary-slag and Final Slag in BF. Steel Res. Int. 2015, 86, 550-556. [CrossRef]

25. Zhang, J. Coexistence Theory of Slag Structure and Its Application to Calculation of Oxidizing Capability of Slag Melts. J. Iron Steel Res. Int. 2003, 10, 1-10.

26. Di, H.; He, Z.-J.; Yan, L.-J.; Qiu, S.; Zhan, W.-L.; Zhang, J.-H. Metallurgical property of mixed burden based on a large scale iron ore droplet testing equipment. Iron Steel 2018, 53, 90-94.

27. Wang, F.J.; Lyu, Q.; Chen, S.J.; Liu, R.; Li, F.M. Research on influence of basicity on dropping performance of vanadium-titanium burden. Iron Steel Vanadium Titan. 2015, 36, 92-96.

28. Li, F.G.; Qi, C.L.; Wang, Y. Influence of FeO on soften-melting properties of primary slag under different slag basicity. Iron Steel 2018, 53, 20-26.

(C) 2020 by the authors. Licensee MDPI, Basel, Switzerland. This article is an open access article distributed under the terms and conditions of the Creative Commons Attribution (CC BY) license (http://creativecommons.org/licenses/by/4.0/). 